https://doi.org/10.19195/0524-4544.329.19

\title{
KAZIMIERZ STRZYCZKOWSKI
}

ORCID: 0000-0002-3227-5979

Akademia Ekonomiczno-Humanistyczna w Warszawie

kazimierzstrzyczkowski@gmail.com

\section{Prawa podstawowe jako źródła celów społecznych i gospodarczych Unii Europejskiej}

\begin{abstract}
Abstrakt: Artykuł przedstawia proces reorientacji celów Unii Europejskiej w szczególności wskutek wprowadzonych zmian podstaw aksjologicznych UE, zwłaszcza społecznej gospodarki rynkowej jako podstawy ustroju gospodarczego wspólnoty, zakładającej równoważność celów gospodarczych i społecznych państw członkowskich. Podstawowym zadaniem opracowania jest udzielenie odpowiedzi na pytanie, czy przewidziane w Traktacie z Lizbony cele gospodarcze i społeczne mają równy status z punktu widzenia prawnych instrumentów zapewniających ich realizację oraz balansowanie (innymi słowy z punktu widzenia spójności regulacji prawnej polityki społecznej i osiągania celów gospodarczych na przykładzie gospodarczych i społecznych praw podstawowych).
\end{abstract}

Słowa kluczowe: rynek wewnętrzny, polityka społeczna, prawa podstawowe, prawo konkurencji.

Problematyka celów Unii Europejskiej jest nierozerwalnie związana z historią integracji europejskiej. Debatę nad kierunkiem tej integracji, w szczególności nad relacją między celami gospodarczymi i społecznymi, zapoczątkowały negocjacje nad traktatem rzymskim ${ }^{1}$. W ostatnim czasie nowym impulsem dyskusji o celach Unii Europejskiej było ustanowienie Traktatu z Lizbony, który wprowadził pluralizm celów gospodarczych (rynku wewnętrznego) i społecznych określonych w polityce społecznej. W okresie poprzedzającym szczyt w Lizbonie w 2000 roku obserwowano niewielkie znaczenie polityki społecznej, natomiast już w trakcie szczytu spójność społeczna została usytuowana na równym poziomie z celami gospodarczymi ${ }^{2}$.

1 Szerzej zob. S. Sciarra, From Strasbourg to Amsterdam: Prospects for the convergence of European social rights policy, [w:] The EU and Human Rights, red. P. Alston, M. Bustelo, J. Heenan, Oxford 2011, s. 474 n.

2 Por. art. 2 i art. 3 TUE.

Prawo 329, 2020

(C) for this edition by CNS 
Ocena relacji między celami gospodarczymi a społecznymi Unii Europejskiej wymaga identyfikacji środków przewidzianych do realizacji celów społecznych, jakimi dysponuje UE, z wyraźnym założeniem, iż wymiar społeczny wspólnoty nie ogranicza się do jej polityki społecznej i konwergencji narodowych modeli społecznych, lecz obejmuje regulacje prawne zapewniające społeczny wymiar politycznej i ekonomicznej integracji europejskiej, przewidujące realizację celów społecznych w ramach przepisów prawnych regulujących europejską przestrzeń gospodarczą.

Wprowadzenie do porządku prawnego Unii Europejskiej praw podstawowych o wymiarze gospodarczym (ekonomicznym) i społecznym jako nowych źródeł celów gospodarczych (ekonomicznych) i społecznych jest następstwem art. 6 TUE, zgodnie z którym Unia uznaje prawa, wolności i zasady określone w Karcie praw podstawowych (dalej: KPP) z 7 grudnia 2000 roku $^{3}$, w brzmieniu dostosowanym 12 grudnia 2007 roku w Strasburgu, która ma taką sama moc jak Traktaty ${ }^{4}$ Kategoryzacja praw podstawowych jako praw gospodarczych i społecznych otwiera jednak problem relacji gospodarki i społecznych praw podstawowych ${ }^{5}$. Karta jest bowiem próbą skorygowania społecznego deficytu w dyskursie o konstytucjonalizacji Unii Europejskiej przez wyeliminowanie niepewności co do statusu i pozycji podstawowych praw socjalnych w porządku prawnym $\mathrm{UE}^{6}$. Oczekuje się wręcz, że KPP będzie miała wpływ na balans między swobodami gospodarczymi a prawami społecznymi ${ }^{7}$, gdyż w piśmiennictwie zauważono, że prawa społeczne zajmują drugorzędną pozycję w systemie praw podstawowych (w przeciwieństwie do wolności gospodarczej promowanej przez integrację gospodarczą) ${ }^{8}$.

\section{Formalna równorzędność praw gospodarczych i społecznych}

$\mathrm{Z}$ formalnego punktu widzenia prawa społeczne są systematycznie sytuowane na równorzędnych pozycjach $\mathrm{z}$ innymi prawami podstawowymi, $\mathrm{w}$ tym z prawami gospodarczymi (ekonomicznymi), jako przejaw uzupełnienia w KPP

3 Jak podkreśla J. Hunt, nie wszyscy akceptują podejście do praw podstawowych zakładające ich kategoryzację i różnice między nimi — eadem, Fair and just working conditions, [w:] Economic and Social Rights under the EU Charter of Fundamental Rights. A Legal Perspective, red. T. Hervey, J. Kenner, Oxford-Portland 2003, s. 47.

${ }^{4}$ Por. C. Semmelmann, The European Union's economic constitution under the Lisbon Treaty: Soulsearching among lawyers - the focus to procedure, „European Law Review” 35, 2010, nr 4, s. 525 .

5 Ibidem.

${ }^{6}$ M. Maduro, The double constitutional life of the Charter of Fundamental Rights of the European Union, [w:] Economic and Social Rights..., s. 286.

7 Ibidem.

8 Ibidem, s. 284. 
„deficytu praw społecznych" praw kwalifikowanych jako prawa podstawowe. Prawa socjalne, obok praw ekonomicznych (gospodarczych), należą jednak do praw drugiej kategorii. Oznacza to, że w sytuacji równej wagi praw kwalifikowanych kolizje między nimi należy rozwiązywać $\mathrm{w}$ drodze odpowiedniego balansu (równowagi) ${ }^{10}$. Niektóre $\mathrm{z}$ tych praw społecznych sprzyjają, a nawet wzmacniają prawa podstawowe o charakterze gospodarczym, niektóre natomiast mogą stanowić ograniczenie realizacji praw gospodarczych, co potwierdza orzecznictwo TSUE ${ }^{11}$.

$\mathrm{W}$ przeciwieństwie do praw społecznych status praw ekonomicznych jest jednak zagwarantowany ${ }^{12}$. Prawa dotyczące swobody prowadzenia działalności gospodarczej, prawa własności, prawa co do swobód rynku wewnętrznego są głębiej zakorzenione i mają większą ochronę prawną na mocy prawa unijnego niż prawa społeczne ${ }^{13}$. Praktyka orzecznicza Trybunału Sprawiedliwości przekonuje, że wśród wymogów uzasadniających wyłączenie swobód rynku wewnętrznego występuje także ochrona praw podstawowych, w tym praw społecznych. W związku z tym należy na wstępie zauważyć znaczenie swobód rynku wewnętrznego dla wolności jednostek w formie zasady prawa unijnego jako gospodarczej strony wolności jednostek. Zakłada ona przestrzeń rynku wewnętrznego dla swobodnej działalności gospodarczej jednostek, której nie można zapewnić za pośrednictwem prawa państw członkowskich. Przestrzeń ta odzwierciedla wyjątkową wartość integracji, co ma szczególne znaczenie dla autonomii osobistej w zróżnicowanej, niejednorodnej wspólnocie politycznej ${ }^{14}$.

Biorąc pod uwagę przyjęte założenie identyfikujące swobody rynku wewnętrznego z gospodarczymi prawami podstawowymi jednostek, należy wskazać, że relacja między swobodami rynku wewnętrznego a prawami społecznymi jest różna - może dotyczyć gospodarczych i społecznych praw podstawowych. Swobody rynku wewnętrznego powinny mieć jednak status praw podstawowych ze względu na to, że reprezentują prawa wyznaczające ramy prawne rynku wewnętrznego, a te zostały wymienione $\mathrm{w} \mathrm{KPP}{ }^{15}$. Prawa podstawowe wymienione w art. 15 i 45 KPP składające się na swobodę przepływu osób i usług również

\section{Ibidem.}

${ }^{10}$ K. Lenaerts, Trybunat Sprawiedliwości Unii Europejskiej a ochrona praw podstawowych, „Europejski Przegląd Sądowy” 2013, nr 1, s. 13.

11 Wyrok TSUE z dnia 14 października 2004 roku w sprawie C-36/02, Omega Spielhallen und Automatenaufstellung-GmbH v. Oberbürgermeisterin der Bundesstadt Bonn, Zb.Orz. 2004, s. I-9609.

12 J. Hunt, op. cit., s. 47.

13 Ibidem.

14 A. von Bogdandy, Podstawowe zasady prawa UE - teoria i doktryna (cz. III), „Europejski Przegląd Sądowy" 2009, nr 10, s. 5 n.

${ }^{15}$ Art. $15-17$ oraz art. 45 KPP. 
zostały zaliczone do praw podstawowych ${ }^{16}$. Do grupy tej nie została natomiast zaliczona przewidziana $\mathrm{w}$ art. $16 \mathrm{KPP}$ wolność prowadzenia działalności gospodarczej, uznana za zasadę wynikającą z prawa unijnego i krajowego, a nie prawo, które może być powoływane przez jednostki przed sądami ${ }^{17}$.

Orzecznictwo TSUE nadało tym prawom równoważny charakter, co oznacza, że w wypadku kolizji między prawem podstawowym (społecznym) a swobodą rynku wewnętrznego należy przyjmować, że są one równorzędne, a co za tym idzie swobody rynku wewnętrznego mogą być ograniczone przez prawa podstawowe, a realizacja praw podstawowych może zostać ograniczona przez wykonywanie swobód rynku wewnętrznego ${ }^{18}$. Biorąc pod uwagę kwalifikację swobód rynku wewnętrznego jako praw podstawowych, należy wskazać, że kolizja swobód rynku wewnętrznego i praw społecznych jest kolizją praw podstawowych. Swobody rynku wewnętrznego nie są bowiem nadrzędne wobec praw podstawowych określonych w KPP, w związku z czym ustanawiające je przepisy traktatowe powinny być interpretowane w sposób nienaruszający wykonywania praw społecznych i obowiązku wyważenia kolidujących praw podstawowych, opierając się na teście proporcjonalności. Takie stanowisko zajmuje Trybunał Sprawiedliwości uznający ochronę praw podstawowych i swobód rynku wewnętrznego za wartości równoważne pod względem mocy prawnej. Równoważenie w tym wypadku oznacza wyważenie jednej i drugiej wartości z punktu widzenia dopuszczalności ich uzasadnionego ograniczenia ${ }^{19}$. Usytuowanie praw socjalnych na równi z gospodarczymi według niektórych autorów jest jednakże w najlepszym razie równoznaczne z ryzykiem niespójności, a w najgorszym — z podstawową sprzecznością (kontradykcją) w konstytucyjnym systemie prawnym ${ }^{20}$.

Trzon konstytucji Unii Europejskiej stanowi integracja gospodarcza w ramach rynku wewnętrznego, którą konstytuują podstawowe wolności gospodarcze. Natomiast status praw socjalnych wydawał się mieć charakter pomocniczy ${ }^{21}$. Przeprowadzone zmiany w obszarze praw socjalnych były ściśle związane z celami dobrze funkcjonującego rynku wewnętrznego. Miały one przede wszystkim zapobiegać zakłóceniom konkurencji, a nie zapewniać realizację celów (wartości)

16 D. Miąsik, [w:] Karta Praw Podstawowych. Komentarz, red. A. Wróbel, Warszawa 2013, s. $613-614$.

17 Ibidem, s. 621; por. E. Skibińska, [w:] Karta Praw Podstawowych..., s. 593-594; A. Bodnar, Karta Praw Podstawowych: zróżnicowany charakter prawny postanowień Karty $i$ ich skutki dla jednostek, sadów i ustawodawcy, [w:] Ochrona praw podstawowych w Unii Europejskiej, red. J. Barcz, Warszawa 2008, s. 156.

18 Opinia Rzecznik Generalnej Trstenjak w sprawie C-271/08, Komisja Europejska v. Republika Federalna Niemiec, pkt 81, 84, 86, 183-188 i 199.

19 Por. uwagi J. Ryszki, Prawa społeczne pracowników a prawa pracodawców-przedsiębiorców na rynku wewnętrznym Unii Europejskiej, Warszawa 2018, s. 144.

20 S. Deakin, J. Browne, Social Rights and market order: Adapting the capality approach, [w:] Economic and Social Rights..., s. 28.

${ }^{21}$ M. Maduro, op. cit., s. 285. 
społecznych. Uzasadnieniem realizacji tych celów (wartości) były cele (wartości) integracji rynkowej, a nie cele (wartości) społeczne. Pod wieloma względami to podejście nadal dominuje w kodzie genetycznym społecznej Unii Europejskiej, nawet w warunkach rozwoju polityki społecznej ${ }^{22}$.

W świetle tej obserwacji prawa socjalne nie są postrzegane jako prawa, z których wynikają określone uprawnienia obywateli. Zamiast tego są one pomyślane, przynajmniej do pewnego momentu, jako instrument niezakłóconej konkurencji lub gwarancja, że konkurencja nie wpłynie na poziom praw socjalnych zapewnionych przez państwa członkowskie ${ }^{23}$. Wiele krajowych praw i polityk socjalnych zostało jednak zakwestionowanych na podstawie przepisów prawnych dotyczących swobód rynku wewnętrznego, ponieważ równowaga między wolnościami gospodarczymi a prawami socjalnymi w konstytucji UE została w dużej mierze określona przez równowagę między integracją gospodarczą w ramach rynku wewnętrznego a krajowymi prawami socjalnymi, a cele (wartości) społeczne nigdy w pełni nie stanowiły niezależnych celów powstającego ustroju Unii Europejskiej $^{24}$.

\section{Prawa podstawowe nie są źródłem kompetencji UE}

Dla podjętych uwag istotne znaczenie mają konsekwencje prawne przewidzianych w Traktatach i w samej Karcie gwarancji mających przeciwdziałać rozszerzeniu kompetencji Unii ${ }^{25}$. Prawa podstawowe w świetle art. 6 ust. 1 TUE oraz art. 51 ust. 2 KPP nie są źródłem nowych kompetencji ani zadań Unii Europejskiej. Zgodnie z klauzulą stand still — zawartą w art. 51 ust. 2 KPP, powtórzoną w art. 6 ust. 1 TUE - Karta nie rozszerza zakresu stosowania prawa UE, nie ustanawia i nie zmienia kompetencji Unii i ogranicza ich rozwinięcie na drodze podobieństwa ${ }^{26}$. Ochrona praw podstawowych w żaden sposób nie rozszerza też kompetencji Unii określonych w traktatach, gdyż podlega ona zasadzie przyznania lub powierzonych uprawnień przewidzianej w art. 5 ust. 1 i 2 TUE. Tym samym prawa społeczne zamieszczone w Karcie podlegają ochronie tylko wtedy i w takim zakresie, w jakim stanowią przedmiot kompetencji Unii Europejskiej. Musi jednak istnieć powiązanie między naruszeniem danego prawa podstawo-

22 Ibidem.

23 Ibidem.

24 Ibidem.

25 Art. 6 ust. 1 zd. 2 TUE; oraz art. 51 ust. 2 KPP. Por. N. Półtorak, Zakres związania państw członkowskich Kartą Praw Podstawowych Unii Europejskiej, „Europejski Przegląd Sądowy” 2014, nr 9, s. 18 .

26 A. Berramdane, Stosowanie Karty Praw Podstawowych UE przez sądy, „Europejski Przegląd Sądowy" 2016, nr 8, s. 5. 
wego a porządkiem prawnym $\mathrm{UE}^{27}$. Prawa podstawowe wiążą przede wszystkim Unię, natomiast państwa członkowskie są jej adresatami jedynie w tak zwanej konstelacji implementacyjnej ${ }^{28}$.

Ochrona praw podstawowych o wymiarze społecznym nie może zatem wiązać się z rozszerzeniem zakresu kompetencji Unii przewidzianych w regulacjach traktatowych. Nierozszerzalność kompetencji społecznych Unii jako zabezpieczenie społecznych praw podstawowych poprzez przyjęcie Karty w sytuacji deficytu europejskiego prawa społecznego można uznać za decydujące do oceny, czy i w jakim zakresie społeczne prawa podstawowe stanowią środek realizacji celów społecznych UE. W konsekwencji KPP ma zastosowanie jako środek realizacji celów społecznych $\mathrm{w}$ takim zakresie, $\mathrm{w}$ jakim są one powiązane z prawem Unii Europejskiej ${ }^{29}$. Jest to oczywiste, gdyż w przeciwnym razie zakres stosowania KPP w odniesieniu do praw społecznych nie byłby identyczny z zakresem wykorzystania tego dokumentu jako ogólnych zasad prawa ${ }^{30}$.

\section{Programowy charakter praw społecznych}

Istotne znaczenie dla miejsca praw społecznych jako instrumentów prawnych realizacji celów społecznych w Unii Europejskiej ma ponadto weryfikacja tych praw w sposób uwzględniający podział postanowień Karty na prawa, wolności $\mathrm{i}$ zasady ${ }^{31}$. Jest to ważne $\mathrm{z}$ uwagi na to, że wiele praw społecznych ma programowy charakter, co uniemożliwia ich sądowe dochodzenie, podobnie jak w wypadku praw podstawowych mających charakter zasad, które mogą być podstawą wykładni i kontroli legalności aktów prawnych. Rozróżnienie między prawami a zasadami nie zostało jednak dokonane przez ich identyfikację bądź definicję ${ }^{32}$. Zidentyfikowanie praw podstawowych o wymiarze społecznym o cechach zarów-

27 K. Lenaerts, op. cit., s. 13. Biorąc pod rozwagę cel przyjęcia Karty, jej status oraz stanowisko państw członkowskich, a także prace przygotowawcze, należy przyjąć, że Trybunał Sprawiedliwości nie może w drodze orzecznictwa rozszerzyć katalogu praw podstawowych określonych w Karcie; zob. A. Wróbel, Komentarz do art. 51 ust. 2 i komentarz do art. 52 Karty Praw Podstawowych, [w:] Karta Praw Podstawowych..., s. 1299 n.

28 A. von Bogdandy, op. cit., s. 10.

29 Wyrok TS z dnia 6 marca 2014 roku w sprawie C-206/13, C. Siracusa v. Regione Sicillia, pkt 24, EU:C:2014:126; por. A. von Bogdandy, op. cit., s. 10.

30 A. Berramdane, op. cit., s. 7.

31 A. Wróbel, O niektórych aspektach koncepcji praw podstawowych UE jako zasad, „Europejski Przegląd Sądowy” 2014, nr 1, s. 104.

32 M. Maduro, op. cit., s. 286. 
no praw, jak i zasad dodatkowo obniża jeszcze poziom pewności prawnej i otwiera drogę aktywności orzeczniczej ${ }^{33}$.

Kwalifikacja praw społecznych zawartych w Karcie jako zasad oznacza węższy niż w wypadku praw zakres ochrony, biorąc pod uwagę, że prawa podstawowe jako prawa są szanowane, natomiast prawa podstawowe jako zasady są jedynie przestrzegane, a ich stosowanie jest wyłącznie popierane ${ }^{34}$. Przepisy KPP zawierające zasady nie mogą przy tym stanowić podstawy roszczeń dochodzonych przed sądami ${ }^{35}$. Tym samym KPP w odniesieniu do społecznych praw podstawowych jako zasad przewiduje niższy standard ochrony prawnej niż w wypadku praw uznanych za prawa podstawowe ${ }^{36}$. Nie można też powoływać się na Kartę, jeśli wszelkich jej postanowień — szczególnie tych, które dotyczą praw socjalnych — nie stosuje się bezpośrednio ${ }^{37}$.

Nie sposób jednak pominąć podkreślanej w piśmiennictwie ewolucji regulacji praw socjalnych UE w kierunku rozszerzania katalogu i nadawania im, tak jak prawom obywatelskim i politycznym, charakteru roszczeniowego (ang. justiciable), w którym zmierza orzecznictwo Trybunału Sprawiedliwości Unii Europejskiej oraz doktryna, w szczególności od momentu włączenia KPP do prawa traktatowego. Realizacja tego kierunku napotyka jednak bariery, przede wszystkim natury ekonomicznej, zróżnicowane w państwach członkowskich Unii Europejskiej, co uniemożliwia nadania tym prawom statusu bezwzględnej wykonalności. Niektóre prawa socjalne potwierdzone przez Kartę są natychmiast skutecznie wykonalne pod względem prawnym, podczas gdy inne mają charakter programowy, wskazując cele, które mają zostać osiągnięte stopniowo ${ }^{38}$. Mówi się nawet, że prawa te mają charakter standardu bądź postulatu ${ }^{39}$. Status bezwzględnej wykonalności mają natomiast należące do pierwszej kategorii prawa obywatelskie i polityczne.

Panuje dość zgodna opinia, że wprowadzenie praw społecznych do Karty dopełnia podstawy aksjologiczne Unii Europejskiej, głównie jako kryteriów wykładni prawa UE oraz wytycznych dla polityki socjalnej, aczkolwiek niektórzy mieli powody, aby wątpić, czy polityka społeczna w rzeczywistości uzyskała równą pozycję z polityką gospodarczą ${ }^{40}$. Ze swej natury prawa te mają bowiem w ograniczonym zakresie charakter roszczeniowy, gdyż ich podstawową funkcją

33 Jak to podkreśla A. Wróbel, dotychczasowe orzecznictwo i doktryna prawa miały i nadal mają poważne wątpliwości, czy na przykład prawo do niedyskryminacyjnego lub równego traktowania ma strukturę zasady czy prawa. Nie uzasadnia to jednak przyjmowania założenia, że prawo to ma strukturę hybrydową; zob. idem, O niektórych aspektach..., s. 106.

34 Art. 51 ust. 1 zd. 2 KPP.

35 A. Berramdane, op. cit., s. 7.

36 A. Wróbel, O niektórych aspektach..., s. 108.

37 A. Berramdane, op. cit., s. 7.

38 M. Maduro, op. cit., s. 285.

39 M. Seweryński, Ewolucja praw socjalnych w Unii Europejskiej, „Europejski Przegląd Sądowy" 2016, nr 8, s. 34.

40 J. Hunt, op. cit., s. 57. 
jest formułowanie celów wspólnoty i państw członkowskich, co usprawiedliwia nadanie im charakteru zasad prawa UE o charakterze wiążącym zarówno UE, jak i państwa członkowskie, które ponoszą ciężar regulacji prawnej przy udziale partnerów społecznych aktualizujących prawa socjalne jako zasady prawa UE odpowiednio do uwarunkowań społeczno-ekonomicznych ${ }^{41}$.

\section{Deficyt traktatowych praw społecznych}

Dokonana analiza charakteru społecznych praw podstawowych przekonuje, iż ich znaczenie jako źródeł celów społecznych obniża deficyt traktatowych kompetencji Unii Europejskiej w zakresie praw społecznych traktowanych jako przeciwwaga dla rozwiązań gospodarczych. Prawa społeczne przewidziane w Karcie podlegają ochronie tylko wtedy i w takim zakresie, w jakim stanowią przedmiot kompetencji Unii Europejskiej. Ochrona praw podstawowych o wymiarze społecznym nie może bowiem się wiązać z rozszerzeniem zakresu kompetencji Unii przewidzianych w regulacjach traktatowych. Karta praw podstawowych ma zastosowanie jako środek realizacji celów społecznych jedynie w takim zakresie, w jakim są one powiązane z prawem UE, co w sytuacji deficytu europejskiego prawa społecznego można uznać za decydujące do oceny, czy i w jakim zakresie społeczne prawa podstawowe są środkiem realizacji celów społecznych UE. W tych warunkach równoważenie celów gospodarczych i społecznych może zapewnić zaangażowanie orzecznictwa Trybunału Sprawiedliwości UE ${ }^{42}$.

W sytuacji niewypracowania jasnych preferencji prawodawstwa społecznego nadal przeważa stan otwartości tekstu prawnego i niekonkretność przepisów prawnych traktowanych jako przeciwwaga dla rozwiązań gospodarczych. Dlatego też jedynym rozwiązaniem jest uznanie, że równoważenie (balans) rozwiązań legislacyjnych w odniesieniu do spraw gospodarczych i społecznych powinno angażować dobrze uzasadnioną metodę case by case w ramach działalności orzeczniczej Trybunału Sprawiedliwości ${ }^{43}$.

Jak podkreśla M. Maduro, konstytucyjny balans (równowaga) między wolnościami gospodarczymi a prawami socjalnymi w znacznym stopniu został ukształtowany przez sądy i strony procesowe, przy czym dominowało tradycyjne podporządkowanie praw socjalnych wolnościom gospodarczym ${ }^{44}$. Przyjęty kierunek orzecznictwa zakładał odmienne traktowanie praw (swobód) gospodarczych i praw społecznych, gdy występowały w relacji kolizyjnej. Zróżnicowanie ochro-

41 Ibidem.

42 C. Semmelmann, op. cit., s. 525.

43 Ibidem, s. 542.

${ }^{4} \mathrm{M}$. Maduro, Striking the elusive balance between economic freedom and social rights in the EU, [w:] The EU and Human Rights, red. P. Alston, Oxford 2011, s. 449-472. 
ny praw społecznych i gospodarczych na rzecz praw gospodarczych uzasadnia odmienny charakter i zakres podstaw prawnych obszarów gospodarczego i społecznego. Sądy wielokrotnie kwestionowały zatem krajowe regulacje dotyczące praw społecznych (sprawiedliwych warunków pracy), podając w uzasadnieniu, że stanowią przeszkodę w aktualizacji (unijnych) wolności gospodarczych ${ }^{45}$. Także na poziomie prawa wtórnego nie obowiązują regulacje określające relacje między prawami gospodarczymi a społecznymi pozostawionymi ocenie TSUE. W orzeczeniach bezpośrednio odnoszących się do praw społecznych ${ }^{46}$ dawało się zauważyć podporządkowanie praw społecznych prawom gospodarczym. Trybunał Sprawiedliwości Unii Europejskiej uznał, że cele społeczne realizowane w ramach polityk społecznych państw członkowskich nie mogą w istocie naruszać praw gospodarczych wynikających z postanowień Traktatów, które prawa te gwarantują ${ }^{47}$. Pomimo promowania spójności gospodarczej i społecznej wynikającej z treści art. 3 ust. 3 TUE, a także z klauzuli społecznej zawartej w art. 9 TFUE nie ma konkretnych rozwiązań legislacyjnych. TSUE nie będzie mógł więc rozwijać interpretacji prawa unijnego na podstawie tych postanowień KPP, które dotyczą praw społecznych nieprzewidzianych w Traktatach, gdyż — jak już podkreślono — postanowienia Karty nie rozszerzają zakresu zastosowania prawa Unii poza jej kompetencje, nie ustanawiają nowych kompetencji czy zadań UE ani nie zmieniają kompetencji i zadań określonych w Traktatach ${ }^{48}$.

Większość autorów wyraża stanowisko, zgodnie z którym w rzeczywistości obszerne orzecznictwo dotyczące spraw egzekwowania praw społeczno-gospodarczych ujawniło trudności z uwagi na wysoki stopień złożoności zagadnień, które podnoszą ${ }^{49}$, a które pogłębia brak spójnego modelu ekonomiczno-społecznego służącego jako podstawa orzecznictwa w dziedzinie spraw społeczno-gospodar$\mathrm{czych}^{50}$. Europejski model społeczny jest na wysokim poziomie abstrakcji, a do tego jest przesiąknięty pluralizmem i różnorodnością, wyrażając ideę równoważenia dwóch zasad konkurencji i solidarności. Skonstruowanie społecznych i ekonomicznych interwencji Unii Europejskiej na podstawie potencjalnego antagonizmu między nimi jest niezgodne z podejściem „trzeciej drogi”, zapewniającej zgodność

45 J. Hunt, op. cit., s. 63.

46 Wyrok TSUE z dnia 11 grudnia 2007 roku w sprawie C-438/05, International Transport Workers' Federation, Finnisch Seamen's Union v. Viking Line ABP, OÜ Viking Line Esti, Zb.Orz. 2007, s. I-10779; oraz wyrok TSUE z dnia 18 grudnia 2007 roku w sprawie C-341/05, Laval un Partneri Ltd v. Svenska Byggnadsabetareförbundet, Zb.Orz. 2007, s. I-11767.

47 Wyrok TSUE z dnia 18 lipca 2007 roku w sprawie C-213/05, Wendy Geven v. Land Nordrhein-Westafalen, Zb.Orz. 2007, s. I-6347.

48 Art. 51 ust. 2 KPP.

49 N. Bernard, A "New governance" approach to economic, social and cultural rights in the EU, [w:] Economic and Social Rights..., s. 265.

50 Ibidem. 
(pojednanie) racjonalności gospodarczej (konkurencyjnej) i społecznej jako pozornie sprzecznych celów, gdyż prawa te tworzą silnie uzależniony związek ${ }^{51}$.

Jak podkreślają K. Lenaerts i P. Foubert, wypracowana przez Trybunał Sprawiedliwości spójna teoria praw społecznych definiuje granice integracji gospodarczej w większym stopniu, niż sugeruje to prawodawstwo Unii Europejskiej, co wszak nie oznacza, że pogląd ten podzielają wszyscy, głównie z powodu niejasnych warunków określających relacje wolności gospodarczych i praw społecznych ${ }^{52}$. Z pewnością natomiast Trybunał, co zauważa J. Hunt, nie wyłączył z języka praw podstawowych praw społecznych, które mogą być sprzeczne z wolnościami gospodarczymi (ekonomicznymi) ${ }^{53}$. KPP jako wskaźnik podstawowych wartości społecznych może bowiem zbudować pluralistyczną europejską konstytucję społeczną, która mogłaby zagwarantować ponadczasowy, skuteczny system ochrony praw ekonomicznych i społecznych w ramach wielopoziomowego porządku prawnego Unii Europejskiej ${ }^{54}$. Jak dostrzeżono w piśmiennictwie, Trybunał określił prawa socjalne jako prawa podstawowe i pragnął przekazać wrażenie, że prawom tym i wolnościom gospodarczym przypisuje tę samą wartość jak w wypadku prawa $U^{55}$. Raz jeszcze należy zatem wskazać, że kolizyjność celów gospodarczych i społecznych jest konsekwencją deficytu integracji społecznej na poziomie integracji europejskiej. W procesie tworzenia warunków do uwzględnienia celów społecznych w Unii Europejskiej istotną rolę odegrało orzecznictwo Trybunału Sprawiedliwości w sprawach tak zwanego Kwartetu Laval ${ }^{56}$.

Pełna świadomość niemożliwości pozostawienia sfery socjalnej poza obszarem integracji europejskiej w warunkach nieistnienia wyraźnie sformułowanych kompetencji społecznych Unii Europejskiej z jednoczesnym dążeniem do europeizacji sfery socjalnej stała się impulsem do sięgnięcia po metody tak zwanego nowego zarządzania (ang. new governance), co oznacza odejście od metody wspólnotowej z wykorzystaniem tradycyjnych instrumentów prawnych i zwrócenie się ku metodzie opartej na elastycznych instrumentach tak zwanego prawa miękkiego (ang. soft law), której przykładem jest otwarta metoda koordynacji (ang. open method of coordination), znajdująca zastosowanie w obszarze zarówno gospodarki, jak i polityki społecznej w różnych jej przejawach. Miejsce niemożliwej do osiągnięcia harmonizacji polityki społecznej zajęła zatem koordynacja rozwiązań prawnych w wypadku konfliktu prawodawstw państw członkowskich Unii Europejskiej w ramach otwartej metody koordynacji, co podniosło znaczenie rozwiązań proceduralnych.

51 J. Hunt, op. cit., s. 57.

52 K. Lenaerts, op. cit., s. 13.

53 J. Hunt, op. cit., s. 63.

54 J. Kenner, Economic and social rights in the EU legal order: The mirage of indivisibility, [w:] Economic and Social Rights..., s. 25.

55 F. de Cecco, State Aid and Economic Constitution, Oxford-Portland 2013, s. 22.

56 Wyrok TSUE z dnia 18 grudnia 2007 roku w sprawie C-341/05. 
Jak zauważa N. Bernard, KPP w odniesieniu do praw społecznych jest użytecznym instrumentem właśnie $\mathrm{w}$ kontekście technik zarządzania opartych na instrumentach prawa miękkiego, a nie działaniach regulacyjnych właściwych organów, bazujących na wyraźnie określonych kompetencjach ${ }^{57}$. Otwarta metoda koordynacji tworzy atrakcyjną alternatywę dla sądowej drogi postępowania, gdyż opiera się na założeniu udziału wszystkich zainteresowanych wdrożeniem Karty w publicznej debacie dotyczącej krajowych planów działania w zakresie praw podstawowych, poprzedzającej procesy decyzyjne na poziomie Unii Europejskiej ${ }^{58}$. Sądowe egzekwowanie praw społecznych i otwarta metoda koordynacji nie są przy tym wzajemnie wykluczającymi się środkami realizacji prawa ekonomiczno-socjalnych, aczkolwiek wiele argumentów przemawia za otwartą metodą koordynacji jako sposobem opracowania kierunków polityki społeczno-gospodarczej, co ma szczególne znaczenie w kontekście krajowych polityk społecznych, gdyż — jak z naciskiem podkreśla J.H.H. Weiler - Unia Europejska potrzebuje czegoś więcej niż katalogu praw podstawowych, a mianowicie polityki praw podstawowych ${ }^{59}$. Podstawowym walorem tego instrumentu polityki społecznej, przy uwzględnieniu zastrzeżeń co do jego skuteczności, głównie z uwagi na brak odpowiednich kompetencji Komisji, jest stworzenie warunków opracowania wspólnych celów strategicznych, które mogą stać się elementami europejskiego modelu społecznego. Mogą one stanowić wytyczne dla państw członkowskich przy ustalaniu precyzyjnej i jasnej równowagi między unijną integracją gospodarczą a integracją o charakterze społecznym. Wymaga to jednak ich dobrej woli i pozytywnego nastawienia, właśnie z uwagi na niewiążący charakter tego rodzaju wytycznych oraz niemożliwość poniesienia odpowiedzialności prawnej na wypadek ich niezastosowania.

\section{Bibliografia}

Bernard N., A "New governance" approach to economic, social and cultural rights in the EU, [w:] Economic and Social Rights under EU Charter of Fundamental Rights. A Legal Perspective, red. T. Hervey, J. Kenner, Oxford-Portland 2003.

Berramdane A., Stosowanie Karty Praw Podstawowych Unii Europejskiej, „Europejski Przegląd Sądowy" 2016, nr 8.

Bodnar A., Charakter prawny postanowień Karty i ich skutki dla jednostek, sadów i ustawodawcy, [w:] Ochrona praw podstawowych w Unii Europejskiej, red. J. Barcz, Warszawa 2008.

Bogdandy A. von, Podstawowe zasady prawa UE - teoria i doktryna (cz. III), „Europejski Przegląd Sądowy" 2009, nr 1.

57 N. Bernard, op. cit., s. 255.

58 Ibidem, s. 267.

59 J.H.H. Weiler, Does the European Union truly need a Charter of Rights?, „European Law Journal" 2000, nr 6, s. 95. 
De Cecco F., State Aid and European Economic Constitution, Oxford-Portland 2013.

Deakin S., Browne J., Social rights and market order: Adapting the capality approach, [w:] Economic and Social Rights under EU Charter of Fundamental Rights. A Legal Perspective, red. T. Hervey, J. Kenner, Oxford-Portland 2003.

Domańska M., Swobody rynku wewnętrznego a prawa podstawowe - refleksje na tle orzecznictwa TS, „Europejski Przegląd Sądowy” 2012, nr 1.

Hunt J., Fair and just working conditions, [w:] Economic and Social Rights under EU Charter of Fundamental Rights. A Legal Perspective, red. T. Hervey, J. Kenner, Oxford-Portland 2003.

Kenner J., Economic and social rights in the EU legal order: The mirage of indivisibility, [w:] Economic and Social Rights under EU Charter of Fundamental Rights. A Legal Perspective, red. T. Hervey, J. Kenner, Oxford-Portland 2003.

Lenaerts K., Trybunat Sprawiedliwości Unii Europejskiej a ochrona praw podstawowych, „Europejski Przegląd Sądowy” 2013, nr 1.

Maduro M., The double constitutional life of the Charter of Fundamental Rights of the European Union, [w:] Economic and Social Rights under EU Charter of Fundamental Rights. A Legal Perspective, red. T. Hervey, J. Kenner, Oxford-Portland 2003.

Maduro M., Striking the elusive balance between economic freedom and social rights, [w:] The EU and Human Rights, red. P. Alston, Oxford 2011.

Miąsik D., [w:] Karta Praw Podstawowych. Komentarz, red. A. Wróbel, Warszawa 2013.

Półtorak N., Zakres zwiazania państw członkowskich Kartą Praw Podstawowych Unii Europejskiej, „Europejski Przegląd Sądowy” 2014, nr 9.

Ryszka J., Prawa spoleczne pracowników a prawa pracodawców-przedsiębiorców na rynku wewnętrznym Unii Europejskiej, Warszawa 2018.

Sciarra S., From Strasbourg to Amsterdam: Prospects for the convergence of European social rights policy, [w:] The EU and Human Rights, red. P. Alston, M. Bustelo, J. Heenan, Oxford 2011.

Semmelmann C., The European Union's economic constitution under the Lisbon Treaty: Soulsearching among lawyers - the focus to procedure, „European Law Review” 35, 2010, nr 4.

Smejkal V., The social market economy goals of article 3 ust. 3 TUE - a task for EU law, „Prague Law Working Papers Series" 3, 2015, nr 1.

Skibińska E., [w:] Karta Praw Podstawowych. Komentarz, red. A. Wróbel, Warszawa 2013.

Szpunar M., Kilka uwag systematyzujacych na temat zakresu stosowania Karty Praw Podstawowych, „Europejski Przegląd Sądowy” 2015, nr 10.

Weiler J.H.H., Does the European Union truly need a Charter of Rights?, „European Law Journal” 2000 , nr 6.

Wróbel A., Komentarz do art. 51 ust. 2 i komentarz do art. 52 Karty Praw Podstawowych, [w:] Karta Praw Podstawowych. Komentarz, red. A. Wróbel, Warszawa 2013.

Wróbel A., O niektórych aspektach koncepcji praw podstawowych UE jako zasad, „Europejski Przegląd Sądowy” 2014, nr 1.

\section{Fundamental rights as sources of social and economic goals of the European Union}

Summary

This paper is an attempt to present the ongoing process of reorientation of the European Union's objectives resulting from changes in its axiological bases, now founded on the assumption of equivalence between economic growth and maintenance of social cohesion. The basic task of the 
article is to address the issue whether the economic and social goals set forth in the Treaty of Lisbon have equal status from the point of view of legal instruments ensuring their implementation and coherence, in other words from the perspective cohesion of the social policy's regulation and the achievement of sustainable economic growth as an example of social and economic fundamental rights.

Keywords: internal market, social policy, fundamental rights, competition law. 